\title{
FORMENNSKA
}

NOREGS

2017

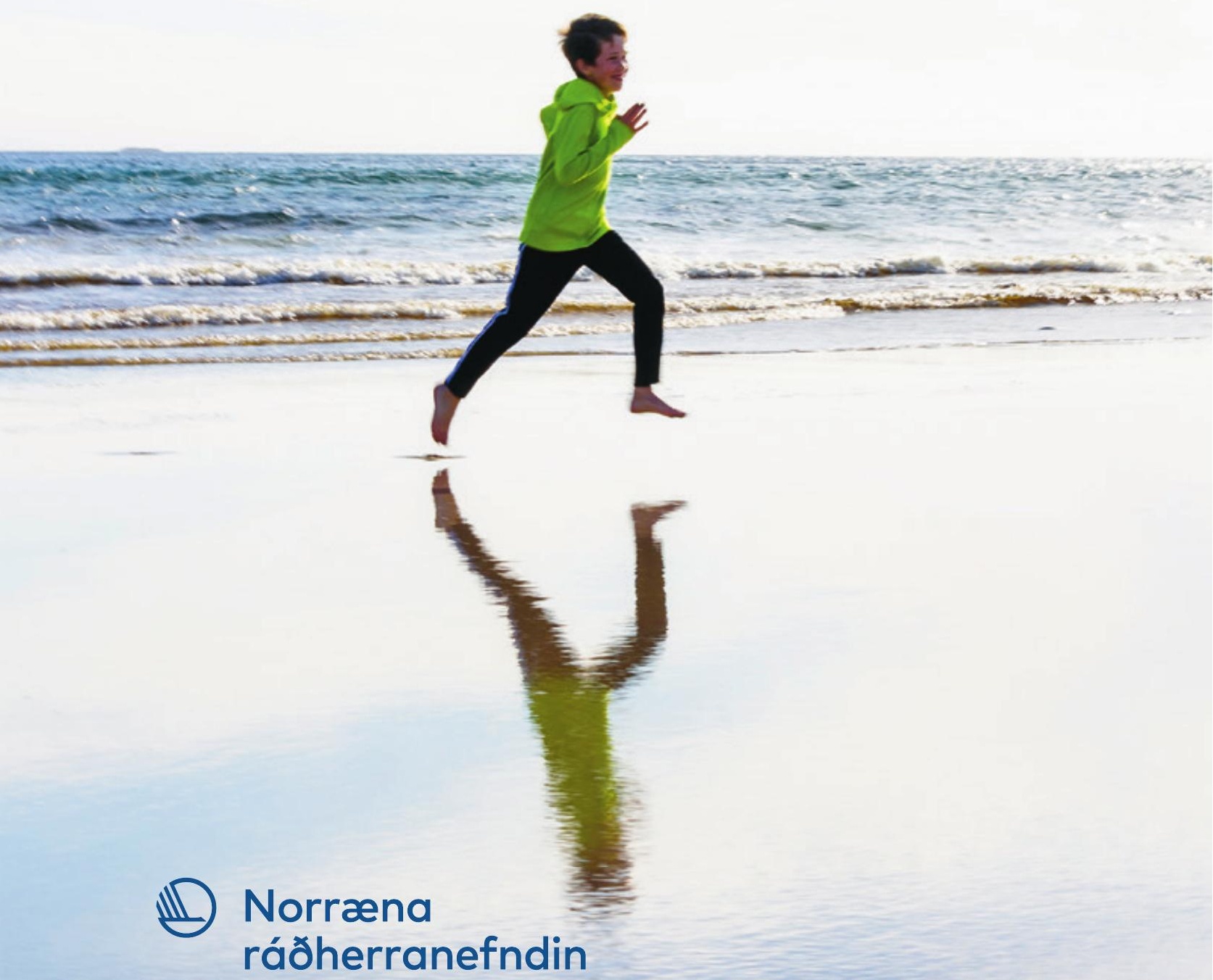




\section{Formennska Noregs 2017}

ISBN 978-92-893-4698-6 (PRINT)

ISBN 978-92-893-4699-3 (PDF)

http://dx.doi.org/10.6027/ANP2016-764

ANP 2016:764

(c) Norræna ráðherranefndin 2016

Umbrot: Mette Agger Tang

Ljósmyndir: Scanpix

Ljósmynd bls. 4, efri mynd: Thomas Haugersveen/Skrifstofu forsætisráðherra

Ljósmynd bls. 4, neðri mynd: Sturlason/Utanríkisráðuneytinu

www.norden.org/nordpub

\section{Norrænt samstarf}

Norræna samstarfið er eitt umfangsmesta svæðasamstarf í heiminum. Samstarfið nær til Danmerkur, Finnlands, Íslands, Noregs og Svípjóðar auk Álandseyja, Færeyja og Grænlands. Norræna samstarfið er pólitískt, efnahagslegt og menningarlegt og skiptir miklu í evrópsku og alpjóðlegu samstarfi. Í norrænu samstarfi er unnið að pví að styrkja stöðu Norðurlanda í sterkri Evrópu. Með norrænu samstarfi er unnið að pví að̃ efla norræna og svæðisbundna hagsmuni í alpjóðlegu umhverfi. Sameiginleg gildi landanna styrkja stöðu Norðurlanda og skipa peim meðal peirra svæða í heiminum par sem nýsköpun og samkeppnishæfni er mest.

Norræna ráôherranefndin

Ved Stranden 18

DK-1061 København K

Sími (+45) 33960200

www.norden.org 
Formennskuáætlun Norðmanna í Norrænu ráðherranefndinni 2017

\section{Efnisyfirlit}

Ávarp forsætisráðherra og

samstarfsráðherra

4

Straumhvörf á Norðurlöndum

Norðurlönd í Evrópu

Norðurlönd og umheimurinn 


\section{Ávarp forsætisráðherra og samstarfsráôherra}

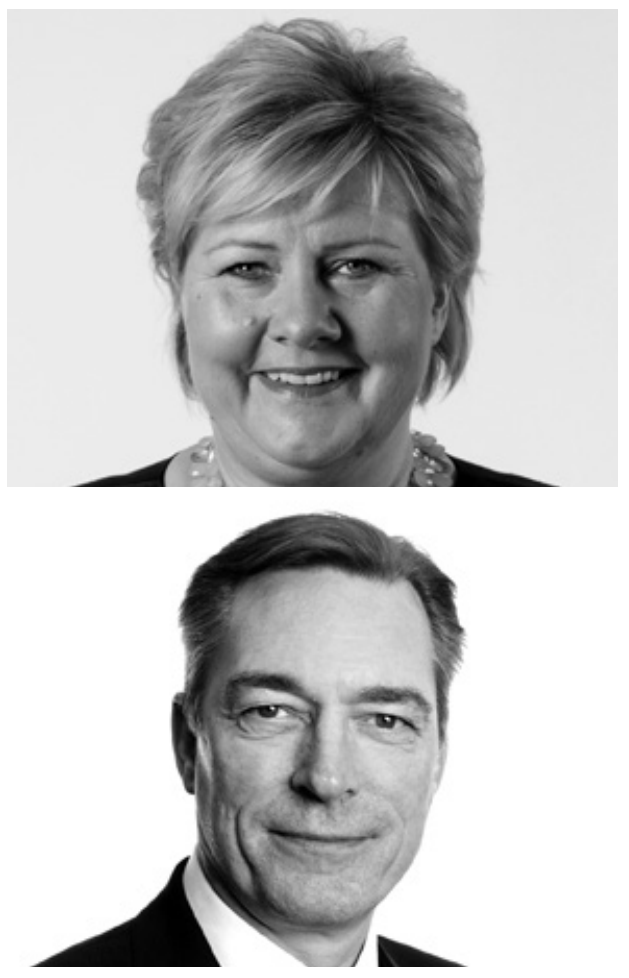

Erna Solberg

Forsætisráðherra Noregs

Frank Bakke-Jensen

Samstarfsráðherra Noregs 
Norðurlönd eru að breytast. Loftslagið tekur breytingum, við stöndum frammi fyrir brýnni pörf á umskiptum í efnahags- og umhverfismálum og lýðfræðileg próun er staðreynd. Próun heimsmála verður æ hraðari, í jákvæðum og neikvæðum skilningi, og veröldin er undirorpin sífelldum breytingum sem eru örari en oft áður.

Daglegt líf á Norðurlöndum á eftir að breytast. Ákvarðanir okkar munu ekki aðeins hafa áhrif á núlifandi kynslóðir heldur einnig pær sem á eftir koma. Stærsta hættan er sú að við bregðumst of seint við peim tæknilegu, efnahagslegu og lýðfræðilegu breytingum sem verða í heiminum.

Á formennskuárinu 2017 viljum við búa Norðurlönd betur undir umræddar breytingar. Sameiginleg menning Norðurlandabúa sem og gildi okkar og hagsmunir gera okkur sérlega vel í stakk búin til pess að takast á við áskoranir og hafa áhrif á próun mála.

Með formennskuáætlun okkar, Straumhvörfum á Norðurlöndum, viljum við auka samkeppnishæfni okkar á tímum umskipta til græns samfélags par sem stefnt er að pví að halda losun í lágmarki. Parísarsamkomulagið felur í sér metnaðarfull markmið sem við eigum að ná innan sameiginlegs evrópsks ramma. Fyrir árin 2030 og 2050 er stefnt að pví að Norðurlönd vísi veginn með skilvirku svæðisbundnu samstarfi um loftslags- og umhverfismál jafnframt pví að auka samkeppnishæfni, hagvöxt og velferð. Með nánara samstarfi um menntamál, rannsóknir og nýsköpun viljum við auka forskot okkar og tryggja Norðurlöndum forystu í umskiptum til græns samfélags um heim allan. Við viljum vera forystusvæði pegar kemur að pví að takast á við lýðfræðilegar breytingar hvort sem um er að ræða málefni eldri borgara, heilbrigðismál eða hvernig við stöndum að aðlögun nýbúa og köllum pá til pátttöku í samfélögum okkar á Norðurlöndum.

Með formennskuáætlun Svía, Norðurlöndum í Evrópu, viljum við efla samstarf okkar um Evrópumál. Öflug rödd Norðurlanda í Evrópuumræðunni er ekki aðeins norrænum pjóðum í hag heldur álfunni í heild sinni. Norðurlönd purfa á öflugri Evrópu að halda. Evrópa parf á öflugum Norðurlöndum að halda. Reynsla Norðurlandapjóða getur orðið öðrum til eftirbreytni á sviðum loftslagsmála, umhverfismála, orkumála, stafrænnar próunar og víðar par sem hagsmunir okkar fara saman. Í ESB- og EES-samstarfi tengjast sameiginlegir hagsmunir okkar próun hins innri markaðar. Norðurlönd eiga einnig á komandi árum að vera meðal peirra hagkerfa í Evrópu sem eru hvað sampættust og samkeppnishæfust og einkennast af miklum hreyfanleika og samstarfi.

Með áætluninni Norðurlönd í umheiminum munum við auka samstarf okkar í utanríkismálum með pví markmiði að takast á við hnattræn viðfangsefni. Norðurlandapjóðir hafa löngum staðið saman í utanríkismálum og njóta trausts umheimsins. Fyrir vikið getum við haft áhrif á gang mála. Á okkar tímum berast alpjóðlegir straumar hraðar til Norðurlanda en hingað til. Breytingarnar eru augljósari en pekkst hefur. Pví er pörf á stefnu hvað varðar pátttöku Norðurlanda í alpjóðlegu samstarfi.

Petta eru prjár meginstoðir formennsku Norðmanna á árinu 2017. Við hlökkum til samstarfsins! 


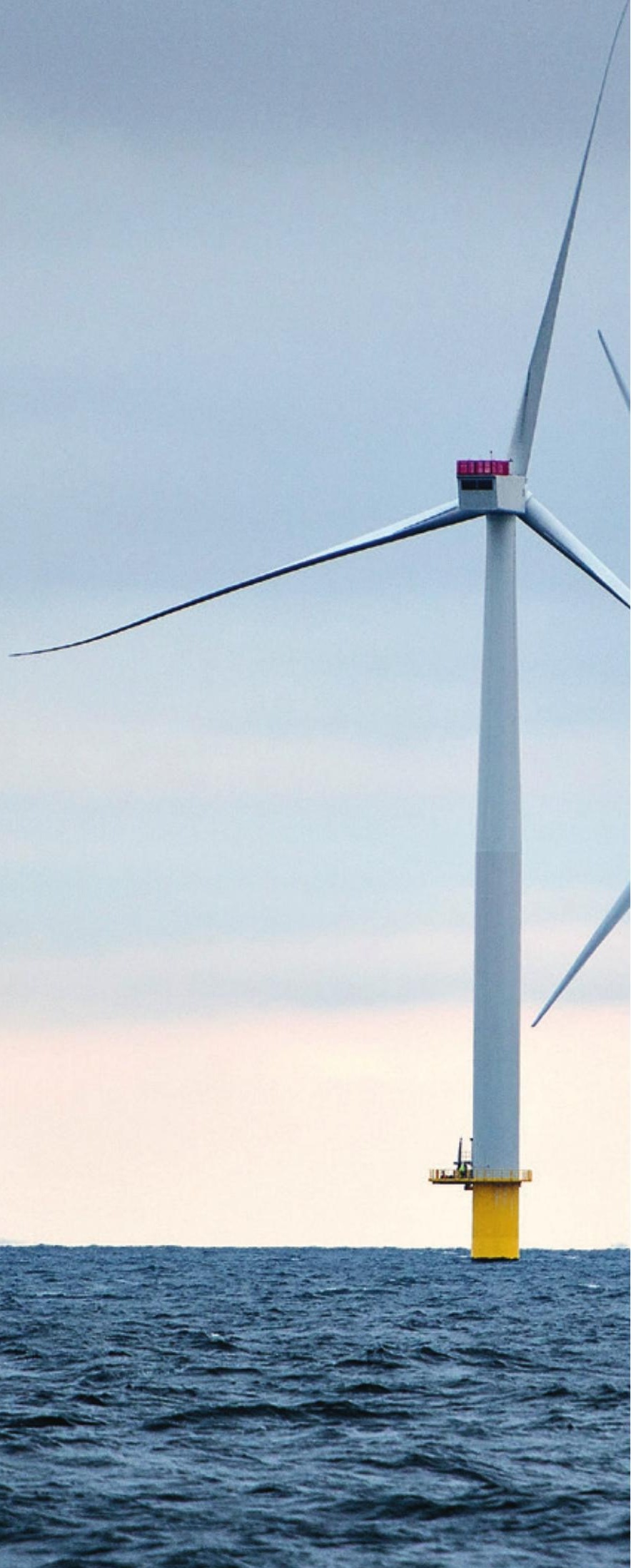




\section{Hagkerfi og loftslagsmál - græn umskipti}

Norðurlönd standa frammi fyrir erfiðum efnahagslegum breytingum á næstu áratugum. Hnattrænn loftslags- og umhverfisvandi kallar á umskipti til græns samfélags um allan heim. Parísarsamkomulagið lagði grundvöllinn að viðamiklum breytingum. Umskiptin verða æ hraðari í Evrópu, Bandaríkjunum og Kína. Unnið er að próun samkeppnishæfra lausna í loftslags- og umhverfismálum í samspili milli rannsókna og próunarstarfs, hertrar stefnu í loftslags- og umhverfismálum, stafrænnar tækni sem og nýrra neyslustrauma og neyslumynstra. Norðurlönd purfa að próa fjölbreyttara atvinnulíf sem er samkeppnishæft í hinu nýja græna hagkerfi heimsins. Umskipti til græns samfélags verða pví efst á baugi pegar Norðmenn gegna formennsku í Norrænu ráðherranefndinni á árinu 2017.

Íbúar Norðurlanda horfa björtum augum til framtíðar. Löndin okkar eru meðal peirra bestu pegar velferð og lífsgæði eru mæld. Norræna líkanið með háu atvinnustigi, trausti milli aðila vinnumarkaðarins og próuðu velferðarríki hefur reynst traust og aðlögunarhæft á tímum hnattvæðingar. Við höfum allar forsendur til að ráða við pessar breytingar.

Íbúar Norðurlanda eru framarlega pegar kemur að færni og nýsköpun og löndin eru meðal eftirsóttustu svæða heimsins. Samanlagt eru hagkerfi okkar í hópi
10-12 stærstu og sampættustu hagkerfa heims. Við erum helstu viðskiptapjóðir hver annarrar. Við vinnum saman að rannsóknum og nýsköpun og njótum góðs af peim mikla hreyfanleika sem einkennir sameiginlegan vinnumarkað og menntasamfélag Norðurlanda. í framtíðinni viljum við halda áfram að próa samstarfið og hreyfanleikann og jafnframt skerpa fyrirbyggjandi aðgerðir og afnám peirra hindrana sem hamla hagvexti á Norðurlöndum.

Um pessar mundir er unnið að ýmsum nýjum verkefnum sem ætlað er að efla norrænt samstarf um umskipti til græns samfélags á árinu 2017.

- Norræna rannsóknaráðið, Norræna nýsköpunarmiðstöðin og Norrænar orkurannsóknir eru prjár stofnanir sem taka pátt i framkvæmd áætlunarinnar Nordic Green Growth Research and Innovation Programme, en hún á að fjármagna bestu norrænu rannsóknarog nýsköpunarverkefnin á sviði umskipta til græns samfélags. Fjárhagsrammi áætlunarinnar er 73 milljónir norskra króna. Verkefnið á að stuðla að sjálfbærri próun, draga úr mengun andrúmslofts frá iðnaði, efla norræna samkeppnisfærni á alpjóðamörkuðum fyrir græna tækni, vörur og pjónustu og jafnframt að skapa nýja pekkingu og stefnu.

- Ráðist verður í stefnumótandi úttekt á samstarfi um umhverfismál par sem markmiðið er að kanna hvernig efla 
megi norrænt samstarf um loftslags- og umhverfismál. Unnið er að samskonar úttekt á orkumálasamstarfinu (Ollilaskýrslunni).

- Ný samstarfsáætlun um nýsköpunarog atvinnustefnu fyrir tímabilið 20182021 mun liggja fyrir á formennskuári Norðmanna par sem skilgreind verða markmið fyrir norrænt samstarf um umskipti til græns samfélags.

- Ráðist verður í gerð nýrrar samstarfsáætlunar á sviði skipulags- og byggðamála fyrir tímabilið 2017-2020 á formennskuári Norðmanna. Í henni verður meðal annars fjallað um svæðisbundið atvinnulíf par sem nýsköpun er í brennidepli.

- Á tímum breytinga á Norðurlöndum er péttbýlisvæðing mikilvægt viðfangsefni. Verkefni um umskipti til græns samfélags og samkeppnisfærni á borgarsvæðum á að stuðla að pví að norrænar borgir hafi lausnir á umhverfis- og loftslagsvandanum. Verkefnið felst í að próa vísa sem mæla aðdráttarafl borga og áhrif sem gæði borga hafa á umhverfi, lýðheilsu og próun aðlaðandi vinnustaða.

- Verkefnið um lífríki hafsins og bláa lífhagkerfið snýst um hlutverk "bláu skóganna" í kolefnishringrásinni og vistkerfum sjávar. Verkefnið felst einnig í að kortleggja magn örplasts í ákveðnum samnorrænum lífverum og kanna hugsanlegar afleiðingar sem örplast og plastúrgangur í sjó hafa á atvinnugreinar bláa lífhagkerfisins. Pá mun verkefnið innihalda aðgerðir gegn glæpastarfsemi í sjávarútvegi sem og útbreiðslu á ostrum úr Kyrrahafinu.
- Verkefnið um græna lífhagkerfið á að auka sjálfbærni i landbúnaði með pví að nýta betur afgangshráefni og úrgang og draga úr sóun í verðmætakeðjunni og hjá neytendum.

- Norræna erfðaauðlindastofnunin (NordGen) og alpjóðlegi fræbankinn á Svalbarða eru mikilvæg fyrir lífhagkerfið og fæðuframleiðslu til framtíðar. Formennska Norðmanna mun efla aðgerðir til að stuðla að sjálfbærri nýtingu erfðaauðlinda.

- Við munum halda áfram norrænu samstarfi um að draga úr losun gróðurhúsalofttegunda í landbúnaði, auka upptöku kolefnis í skógum og jarðvegi og laga atvinnugreinina að loftslagsbreytingum.

Stjórnsýsluhindranaráðið er pólitískt skipað af ríkisstjórnum Norðurlanda. Verkefni ráðsins er að greiða fyrir frjálsri för einstaklinga og fyrirtækja um Norðurlönd. Afnám stjórnsýsluhindrana verður í forgangi á formennskuári Norðmanna sem liður í aðgerðum sem tengjast straumhvörfum og samkeppnisfærni á Norðurlöndum. Afnám stjórnsýsluhindrana skapar störf, eykur samkeppnisfærni og stuðlar að hagvexti. 


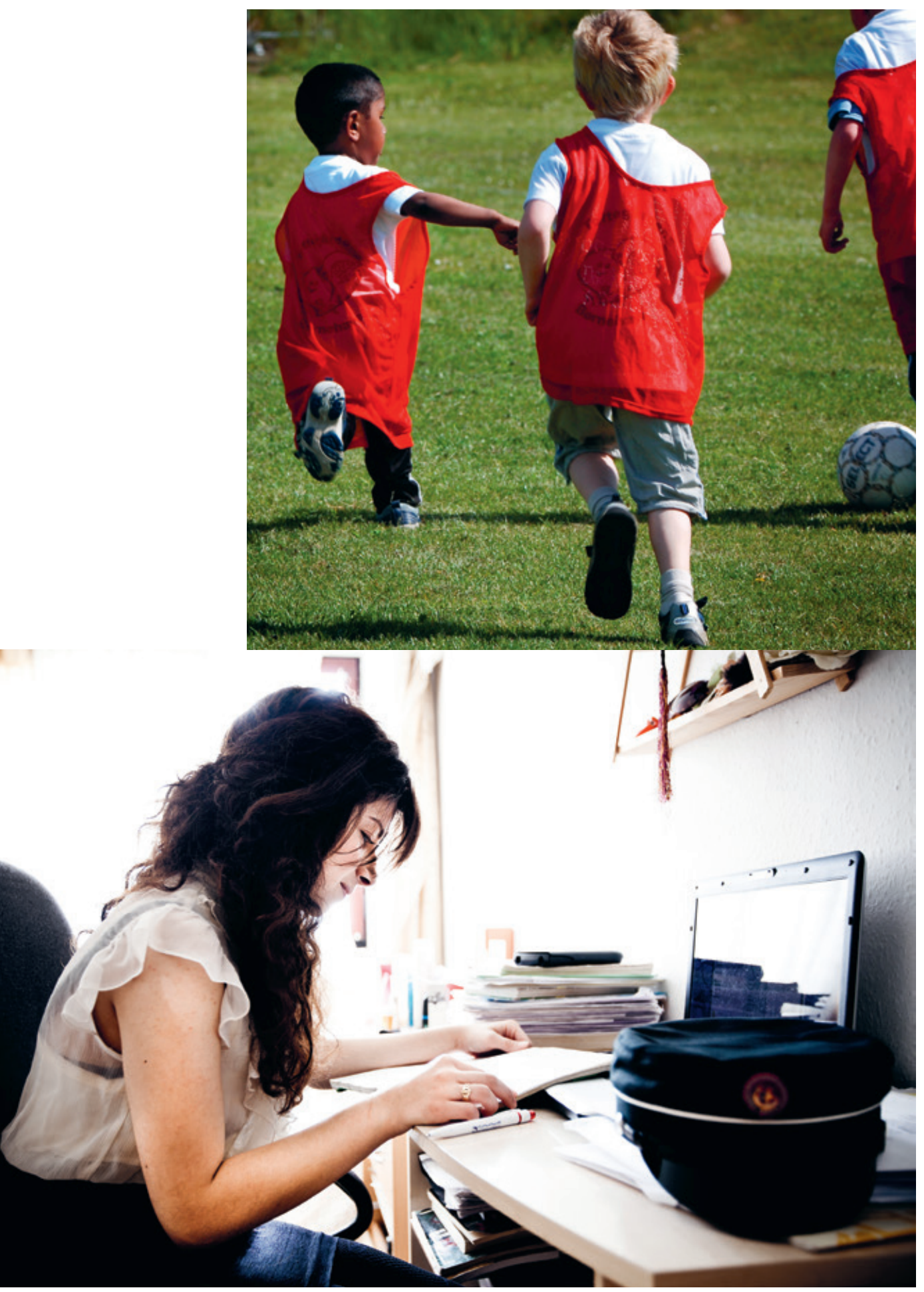




\section{Lýðfræðilegar breytingar - aðlögun og virk pátttaka}

Próun í Evrópu á undanförnum árum hefur leitt í ljós að fólksflutningar og aðlögun nýbúa eru helstu pólitísku, félagslegu og efnahagslegu viðfangsefni álfunnar um pessar mundir. Pað er sameiginleg ábyrgð okkar allra að vel takist til með aðlögun og samfélagspátttöku nýbúa á Norðurlöndum. Jafnframt efnahagsleg og félagsleg nauðsyn. Samfélög Norðurlanda standa frammi fyrir stórum verkefnum en bau hafa einnig góðar forsendur til að ná árangri og vera öðrum löndum Evrópu og víðar til eftirbreytni.

Á formennskuári Norðmanna verður ráðist í breiða norræna samstarfsáætlun um aðlögunarmál par sem áhersla er lögð á próun og miðlun pekkingar og reynslu á pessu sviði. Norðmenn vilja efla norrænar aðlögunaraðgerðir enn frekar.

Verkefni um hlutverk menningarlífs og sjálfboðastarfs fyrir aðlögun og pátttöku á að stuðla að pví að gera norræn samfélög opnari. Í mörgum nærsamfélögum og sveitarfélögum eru menning, ípróttir og ýmiss konar félagastarfsemi helsti vettvangur fólks fyrir utan vinnu og skóla. Menningarog félagslíf sem er aðgengilegt og hvetur til pátttöku veitir nýbúum mikilvæg tækifæri til að kynnast fólki í nærsamfélaginu, æfa sig í tungumálinu, nýta og sýna fram á færni sína og skynja sig sem hluta af heildinni.

Á sviði menntamála og rannsókna verður ráðist í verkefni sem felst í að kortleggja og próa skilvirk líkön fyrir mat á erlendri menntun og starfsréttindum. Með bættri yfirsýn yfir pau kerfi sem notuð eru á Norðurlöndum og pegar pau hafa verið samhæfð eftir pví sem við á verður hægt að flýta fyrir og bæta aðlögun einstaklinga sem og nýtingu mannauðsins.

Priggja ára verkefni verður ýtt úr vör um pverfaglegar aðgerðir fyrir börn og ungmenni sem standa höllum fæti. Verkefninu er ætlað að skila okkur ákveðnum úrræðum vegna síaukinna vandamála barna og ungmenna sem koma til kasta sveitarfélaga hvarvetna á Norðurlöndum. Viðfangsefnin snúa einkum að menntun, atvinnu, heilbrigðispjónustu, barnavernd, búsetu og aðlögun.

Atvinna, menntun og tungumál eru talin lykillinn að vel heppnaðri aðlögun og nýrri verðmætasköpun og hvernig koma má í veg fyrir útskúfun einstaklinga og innrætingu öfgastefnu. Norðmenn vilja vinna áfram að verkefninu um lýðræði, aðlögun og öryggi, par sem markmiðið er að efla skólann sem miðstöð aðlögunar og virkrar samfélagspátttöku. 


\section{Samstarf í heilbrigððismálum}

Norðmenn munu á formennskuári sínu styðjast við tillögur stefnumótandi úttektar á norrænu heilbrigðismálasamstarfi (Könberg-skýrslunnar).

- Við ráðumst í verkefni í peim tilgangi að auka pekkingu á sýklalyfjaónæmi og semja norræna samskiptaáætlun par sem markmiðið er að draga úr notkun sýklalyfja. Sýklalyfjaónæmi er sívaxandi vandamál og veruleg ógn við heilbrigði um heim allan.

- Sérverkefni um heilbrigðisgögn og íhlutandi klínískar rannsóknir á að stuðla að pví að við uppgötvum fyrr orsakir sjúkdóma og próum einstaklingsmiðaðri fyrirbyggjandi aðgerðir og meðferðir í heilbrigðispjónustu. Aukið norrænt samstarf um klínískar rannsóknir og skráningarrannsóknir mun auka samkeppnisfærni pekkingarhagkerfisins.
- Á árinu 2017 munum við kanna möguleika á að samræma siðfræðilegt sampykki á norrænum rannsóknarverkefnum. Samræming á siðfræðilegu sampykki myndi spara mikinn tíma og fé og auka um leið samkeppnisfærni Norðurlanda. Verkefnið á að greiða fyrir innleiðingu á nýrri ESB-tilskipun um klínískar lyfjarannsóknir og norrænu samstarfi um heilbrigðisrannsóknir.

- Við munum einnig kanna möguleika á að stofna norrænt sýndarsetur fyrir rannsóknir á heilbrigðisgögnum.

Markmiðið verður að koma á rafrænum innviðum sem auðvelda skipti á heilbrigðisgögnum milli norrænu ríkjanna. 


\section{Norðurlönd í Evrópu}

- öflugra norrænt samstarf um Evrópumál

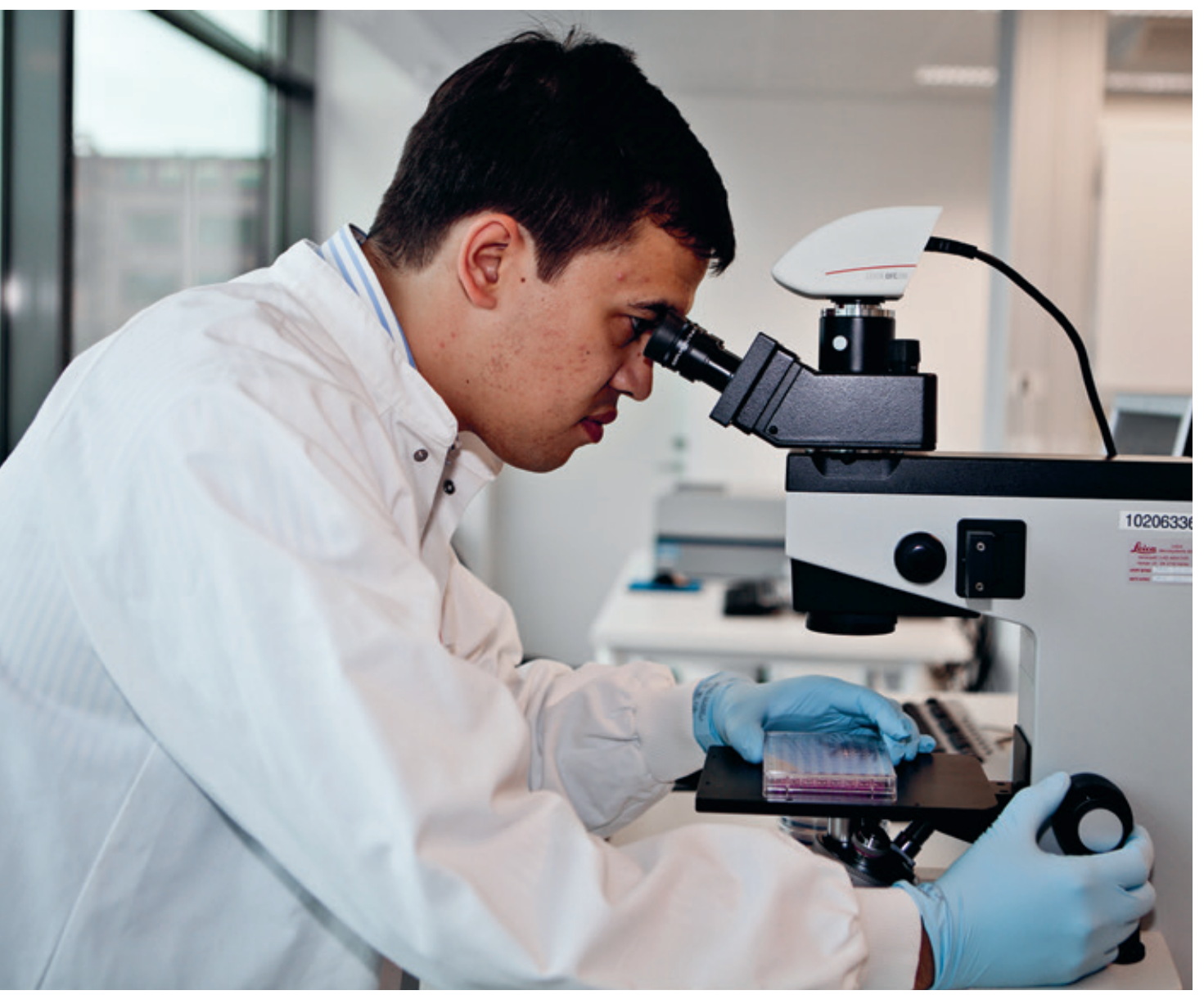


Norðurlönd eru hluti af Evrópusamfélaginu. Aðild okkar að ESB og EES mótar daglegt líf Norðurlandabúa. Norðurlönd geta verið öðrum hvatning og haft áhrif á próun Evrópu.

Sífellt reynir á samstarf Evrópupjóða. Hagvöxturinn er ójafn og of mörg ungmenni eru án atvinnu. Viðfangsefni vegna fólksflutninga eru viðvarandi. E oftar eru lýðræðisleg gildi dregin í efa um leið og andstæður skerpast í samfélögum Evrópu. Öryggisástandið í Evrópu hefur breyst.

Viðfangsefni Evrópu eru einnig viðfangsefni Norðurlanda. Evrópusamstarfið varðar grundvallarhagsmuni okkar í utanríkis- og efnahagsmálum. Hinn innri markaður skiptir sköpum fyrir hagkerfi landa okkar. Nánara samstarf um Evrópumál mun greiða fyrir efnahagslegri aðlögun og hreyfanleika og koma i veg fyrir hömlur á hagvexti á Norðurlöndum.

Við viljum standa vörð um samfélag Evrópu og styðja við pau öfl sem vilja pétta raðir evrópskra pjóða. Við viljum vera öflugur stuðningur við pá Evrópu sem stendur vörð um frjálslynd gildi og mannréttindi og axlar ábyrgð á eigin öryggi. Hagsmunir okkar fá betri hljómgrunn ef sjónarmið Norðurlanda eiga samleið með sjónarmiðum Evrópu. Norðurlönd eiga að stuðla að pví að Evrópa haldi forystuhlutverki sínu eins og ESB hefur sýnt með stefnu sinni í loftslagsmálum.

Norrænt samstarf um Evrópumál hefur aukist á síðari árum. Norðmenn munu fylgja eftir áherslu finnsku formennskunnar á samstarf um Evrópumál. Á árinu 2017 munum við beita okkur fyrir pví að auka sýnileika Norðurlanda í Brussel og samspil ríkjanna á sviðum par sem við eigum sameiginlegra hagsmuna að gæta.

Efnislega leggjum við áherslu á prjú stefnumótandi svið sem varða hagsmuni ríkjanna og par sem Norðurlönd eru og eiga að vera forystusvæði en pau eru orkumál, loftslags- og umhverfismál og stafræn próun.

Nú liggur fyrir að semja nýja norræna samstarfsáætlun um orkumál 2018-2021 par sem meðal annars er stuðst við stefnumótandi úttekt á orkusamstarfinu (Ollila-skýrsluna). Markmið okkar er að Norðurlönd verði hér eftir sem hingað til fyrirmynd við próun Orkusambandsins og hins evrópska raforkumarkaðar, og að ríkin eigi náið samstarf um próun reglugerða ESB á pessu sviði. Orkumálasamstarfið felst einnig í samstarfi um rannsóknir og próun innan ramma Norrænna orkurannsókna (NEF).

í loftslags- og umhverfismálum er markmiðið að norrænt samstarf leggi sitt af mörkum til metnaðarfullrar og skilvirkrar Evrópustefnu í loftslagsmálum í samræmi við Parísarsamkomulagið og til markviss samstarfs um að draga úr losun.

Stafræn tækni er lykilpáttur í próun samkeppnisfærni i Evrópu. Norðurlönd eiga að vera faglegt, nýskapandi og próttmikið svæði stafrænnar próunar á vörum, pjónustu og pekkingu. Við viljum leggja okkar af mörkum til stefnumótunar ESB og byggja áfram á pví norræna samstarfi sem fyrir er. 


\section{Norðurlönd og umheimurinn}

- markvisst norrænt samstarf um utanríkismál

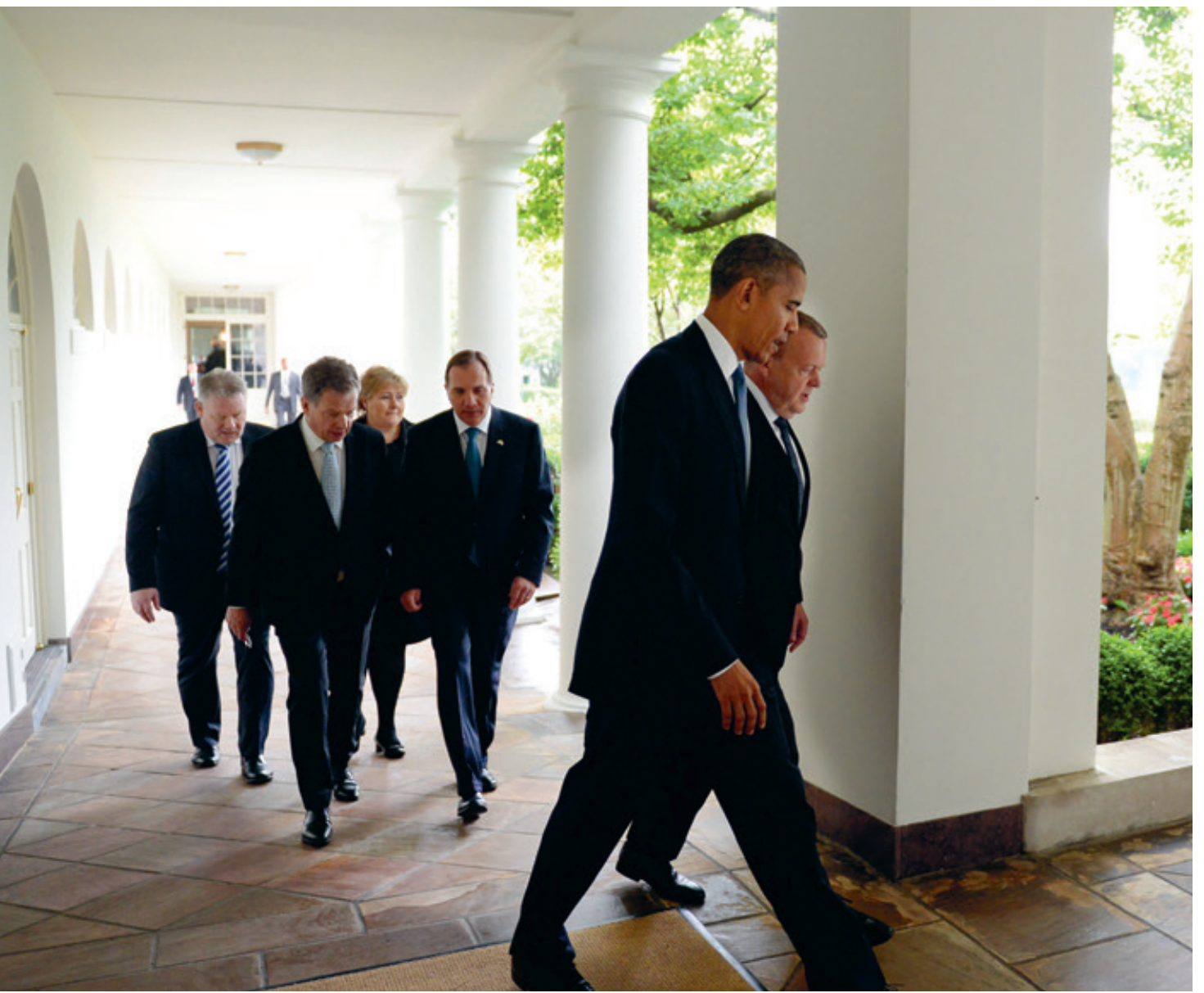


Norrænu pjóðirnar deila sameiginlegum hagsmunum og gildum. Daglegt líf á Norðurlöndum hefur á undanförnum árum orðið fyrir beinni áhrifum af próun albjóðamála en áður var. Erfiðleikarnir færast æ nær. Styrjaldir og átök suður og austur af Miðjarðarhafi hafa bein áhrif á öryggisástandið á meginlandi Evrópu. Ríki i NorðurAfríku og Miðausturlöndum hrynja. Lífsviðurværi fólks hverfur. íbúarnir hrekjast á flótta. Sum ríki eru orðin griðastaðir fyrir hryðjuverkahópa. Sótt er að tjáningarfrelsinu. Verndarstefna og pjóðernishyggja ógna gagnsæinu. pjóðarétturinn er dreginn í efa.

Alpjóðlegir straumar berast æ hraðar til Norðurlanda. Norðurlönd purfa að marka stefnu í heimsmálum.

Á sama tíma eru ýmis jákvæð teikn á lofti. Dregið hefur úr fátækt í heiminum, náðst hefur nýtt og metnaðarfullt samkomulag í loftslagsmálum, fleiri börn fá menntun og betri heilbrigðispjónustu og hagvöxtur heldur áfram í Asíu og Afríku. Við eigum að beita okkur fyrir pví að sameiginleg gæði heimsins verði varðveitt og próuð.
Sameinuðu pjóðirnar gegna einkar mikilvægu hlutverki og við viljum viðhalda áhuga Norðurlanda á málefnum SP. Norðurlönd eiga áfram að vera vænlegur samstarfsaðili í mikilvægum alpjóðlegum málefnum.

Pátttaka Norrænu ráðherranefndarinnar í alpjóðamálum kallast á við óformlegt samráð landanna um utanríkis- og öryggismál og pannig næst mikið gagnkvæmt notagildi. Um er að ræða sjálfsögð viðbrögð við pví að skilin milli innanríkismála og utanríkismála verða æ óljósari. Við munum beita okkur fyrir bví að efla formlegt og óformlegt samstarf Norðurlanda um utanríkismál enn frekar.

Við purfum á sameiginlegri pekkingu og skilningi að halda á straumum í albjóðaog efnahagsmálum. Á árinu 2017 munu Norðmenn próa samstarf milli utanríkismálastofnana landanna enn frekar með pví að styrkja sameiginleg rannsóknarverkefni og ráðstefnur. Með pessu er ætlunin að dýpka samstarfið í utanríkismálum enn frekar og vekja athygli á norrænu samstarfi í utanríkismálum.

Frumkvæði forsætisráðherranna á að greiða fyrir sameiginlegum aðgerðum landanna til að bregðast við alpjóðlegri eftirspurn eftir nýstárlegum lausnum á viðfangsefnum samfélagsins par sem Norðurlönd búa yfir kjarnafærni. Pemu í forgangi eru „Nordic Green", "Nordic Food and Welfare" og "Nordic Gender Effect". Fjárhagsrammi til pessara viðfangsefna er 30 milljónir danskra króna í prjú ár. Til viðbótar koma fjárveitingar frá Norrænu nýsköpunarmiðstöðinni og öðrum norrænum stofnunum. 
Norðurlönd eiga að vera sýnileg og auðpekkt. Með samstarfi náum við til fleiri einstaklinga og stærri markaða og eftirspurn eftir norrænni menningu og listum eykst stöðugt. Allt árið 2017 fer fram norræn hátíð í menningarmiðstöðinni Southbank Centre í Lundúnum, par sem kynnt verður allt litróf norrænnar menningar og lista.

Verkefni um "vörumerki Norðurlanda" mun eiga sinn pátt í að vekja athygli pegar norræn stjórnvöld og fyrirtæki fylgja eftir hagsmunum sínum erlendis. Náið samstarf norrænna sendiráða, einkum samhýsing, gefur mikinn virðisauka bæði fyrir kynningu á Norðurlöndum og samstarf um utanríkismál.

Norrænt samstarf á grannsvæðum okkar gegnir sérstöku hlutverki. Skrifstofur
Norrænu ráðherranefndarinnar í Eystrasaltsríkjunum fögnuðu 25 ára afmæli á árinu 2016. Samstarfið við Eystrasaltsríkin tekur mið af sameiginlegum hagsmunum landanna. Sökum peirrar stöðu sem komin er upp í öryggismálum er samstarf við pau nú í brennidepli. Norræna ráðherranefndin verður áfram mikilvægur samstarfsaðili Eistlands, Lettlands og Litháens, meðal annars í málum sem varða stuðning við frjálsa og óháða fjölmiðla, menningu og orkuöryggi. Nordplus-áætlunin stuðlar að hreyfanleika milli menntastofnana á Norðurlöndum og í Eystrasaltsríkjunum. EES-sjóðir eru annað mikilvægt tæki sem pjónar sameiginlegum hagsmunum Norðurlanda í Eystrasaltsríkjunum. Við munum nota EES-sjóðina til að koma á samstarfi við Eystrasaltsríkin um utanríkismál á sviðum sem stuðla að stöðugleika og próun á svæðinu. 
Ný Norðurlönd 2.0

Markmiðið með umbótastarfi sem ber yfirskriftina Ný Norðurlönd 2.0 er að auka sveigjanleika og skilvirkni hjá Norrænu ráðherranefndinni og losa um fjármagn til pólitískra forgangsverkefna hverju sinni. Að tillögu framkvæmdastjóra Norrænu ráðherranefndarinnar sambykktu samstarfsráoherrarnir eftirfarandi markmið fyrir umbótastarfið:

1. Norðurlönd verði pað svæði heimsins par sem sampætting er lengst á veg komin.

2. Norrænt samstarf stuðli að sjálfbærum hagvexti á Norðurlöndum.

3. Norrænt samstarf skipti máli fyrir almenning á Norðurlöndum.

4. Norræna fjárhagsáætlunin nýtist betur sem stjórntæki.

5. Skipulag ráðherranefndarinnar verði lagað að nýjum áherslum.

6. Efnt verði til funda eftir pörfum um mál sem eru efst á baugi hverju sinni. Sérstök ráðherranefnd fjalli um aðlögun nýrra íbúa.

7. Aukið samspil ráðherra og embættismanna.

8. Öflugra samstarf embættismanna.

9. Heildrænna norrænt samstarf innan sem utan vébanda Norrænu ráðherranefndarinnar.

10. Forsætisráðherrarnir móti almenna stefnu í norrænu samstarfi.

11. Greiningarfærni verði aukin meðal starfsfólks Norrænu ráðherranefndarinnar. 


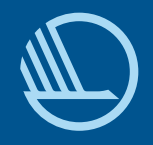

Norræna ráôherranefndin

Ved Stranden 18

DK-1061 København K

www.norden.org 